\title{
NITROGEN REMOVAL FROM LANDFILL LEACHATE BY CHEMICAL AND BIOLOGICAL
TREATMENT: PROCESS COMPARISON
}

\author{
Andrii Butkovskyi \\ Karin Jönsson \\ Lund University, Sweden
}

\begin{abstract}
The efficiency of nitrogen removal from leachate by different chemical and biological methods was explored. The leachate was derived from Filborna landfill (NSR AB, Helsingborg, Sweden) and was characterized as an old leachate with $\mathrm{pH}=8.0$ and comparatively low concentrations of nitrogen and organic compounds (ca. $150 \mathrm{mg} / 1 \mathrm{NH}_{4}-\mathrm{N}$ and $500 \mathrm{mg} / \mathrm{l} \mathrm{COD}$ ). Three treatment processes were tested in lab-scale experiments; combined nitrification and denitrification in a sequencing-batch reactor (SBR), one-reactor nitritation-anammox process in a moving-bed biofilm reactor (MBBR) in sequencing-batch configuration and nitrogen precipitation in the form of magnesium-ammonium-phosphate (MAP). State-of-the-art of these processes is described.

The conventional combined nitrification/denitrification process allowed $99 \%$ removal of inorganic nitrogen with $23 \mathrm{mg} \mathrm{NH}-\mathrm{N} /(1 \cdot \mathrm{h})$ being the highest nitrification rate achieved. Aeration during nitrification step and addition of carbon source according to the stoichiometric ratio for denitrification was required, accounting for the operational costs. The nitritation-anammox process also allowed 99\% removal of inorganic nitrogen with $3.7 \mathrm{~g} \mathrm{NH}_{4}-$ $\mathrm{N} /\left(\mathrm{m}^{2} \cdot \mathrm{d}\right)$ being the highest process rate achieved while running the reactor at $25^{\circ} \mathrm{C}$ and $\mathrm{pH}$ 8.0. The process is advantageous in comparison with the conventional biological removal process, as oxygen consumption is lower and addition of carbon source is not required. With MAP precipitation at the optimal $\mathrm{Mg}: \mathrm{N}: \mathrm{P}$ ratio (1.2:1:1) only $78 \%$ removal of inorganic nitrogen was achieved. The precipitation process led to a significant increase of phosphorous concentrations in the effluent, while external magnesium and phosphorous sources to be added resulted in high process costs. Detailed descriptions of the processes and obtained results are given in the article.

Comparing the three processes, conclusions are drawn that it is possible to achieve effluent nitrogen requirements $(15 \mathrm{mg} \mathrm{N} / \mathrm{l})$ by treatment of leachate with both tested biological processes, but not with MAP precipitation. One-reactor nitritation-anammox would require the lowest operational costs, while MAP precipitation - the highest.
\end{abstract}

\section{KEYWORDS}

Leachate, nitrogen removal, sequencing batch reactor, Anammox, magnesium ammonium phosphate (struvite), moving-bed biofilm reactor 


\section{INTRODUCTION}

Landfill leachate is defined as any liquid that percolates through or drains from solid waste and extracts dissolved, suspended and/or microbial contaminants from it [1]. Though landfilling of organic waste is prohibited in Sweden since 2005 [2], existing landfills will continue to produce leachates contaminated with organic substances. In addition, nitrogen and toxic substances are also present in leachate. Altogether, this will constitute an important challenge for environmental protection over the next decades.

Landfill leachate is today treated in Sweden mainly at municipal wastewater treatment plants (WWTPs) together with wastewater from households as well as other types of industrial wastewaters. On-site pre-treatment is often carried out before discharge to the WWTP [3]. However, municipal WWTPs often refuse accepting leachate from landfill sites, due to several reasons. First of all, according to the so-called "sludge agreement" between Swedish Environmental Protection Agency (SEPA), Federation of Swedish Farmers and Swedish Water and Wastewater Organization (SWWA), a WWTP should not accept any leachate, unless it is proved harmless, in case the sludge from the plant is going to be utilized as fertilizer on agricultural land [4]. Secondly, leachate components might, in rare cases, have a negative impact on the treatment processes. Moreover, there is a financial interest for landfill operators to introduce their own cost-efficient on-site leachate treatment systems, as WWTPs charge them both for the volume of incoming leachate and nutrients concentrations, which exceed certain values. Hence, design and evaluation of methods for on-site leachate treatment are required. The proper combination of treatment methods will allow the appropriate removal of target contaminants with the lowest costs involved.

The main leachate pollutants that have to be removed are organic compounds, nutrients, heavy metals and suspended solids. Nitrogen, being one of the most important causes of eutrophication, has to be reduced foremost among the nutrients. Its concentration is several times higher in leachate than in municipal wastewater. High nitrogen concentrations and leachate toxicity create limitations for leachate treatment by conventional activated sludge process in a continuous-flow reactor.

Reviews on leachate treatment methods mention a number of treatment processes successfully applied for nitrogen removal from leachate - combined nitrification-denitrification in a sequencing batch reactor, chemical precipitation as magnesium ammonium phosphate (MAP) and ammonia air-stripping $[5,6]$. Less sophisticated methods, such as irrigation, infiltration and recirculation are also used. However they may cause groundwater pollution and other environmental problems [5]. Novel nitrogen removal technologies, such as ammonium removal over nitrite (Sharon) and combination of nitritation and anoxic ammonium oxidation (Anammox), can be also applied for leachate treatment. [7]

Combined nitrification-denitrification in a sequencing batch reactor is widely applied for leachate treatment. The first step of the process is the oxidation of ammonia to nitrate under aerobic conditions and the second step - nitrate reduction to nitrogen gas in anoxic conditions. Aeration (in the first phase) and addition of external carbon source (in the second phase) constitute the main expenses. Another method used for nitrogen elimination from leachate is precipitation of magnesium ammonium phosphate $\left(\mathrm{MgNH}_{4} \mathrm{PO}_{4} \cdot 6 \mathrm{H}_{2} \mathrm{O}\right)$, which is also known as struvite. The magnesium compound $\left(\mathrm{Mg}(\mathrm{OH})_{2}, \mathrm{MgO}, \mathrm{MgCl}_{2}\right.$ etc) and phosphoric acid $\left(\mathrm{H}_{3} \mathrm{PO}_{4}\right)$ or salts have to be dosed, as $\mathrm{Mg}$ - and P-containing substances usually occur in leachate in low concentrations, in comparison to the amount of ammonium, which has to be removed. In spite of high process costs and necessity of phosphorous addition to the wastewater, this alternative has some advantages, for example struvite can be used as a valuable fertilizer. The third method, ammonia air stripping requires significant costs for $\mathrm{pH}$ adjustment before and after the process and treatment of ammonia-polluted air. 
Novel wastewater treatment processes, which aim at the decrease of treatment costs, draw much attention since the 90's. Anaerobic (or, more correct, anoxic) ammonium oxidation, discovered a couple of decades ago, is a microbiological conversion of ammonium to nitrogen gas with nitrite used as the electron acceptor instead of oxygen. The process is based on the metabolism of a particular group of chemoautotrophic anammox bacteria. To provide them nitrite, partial nitritation of ammonium in the wastewater should be carried out beforehand. This could be done either in a separate or in the same reactor. Anammox process is more efficient than conventional biological nitrogen removal, as it doesn't require addition of a carbon source, reduce aeration expenses and minimize sludge production. The experience of the first full-scale one-reactor niritation-anammox process in Sweden, which is used for treatment of reject water at Himmersfjärden WWTP (Stockholm), proves that costs for nitrogen removal could be reduced by $40 \%$ [8]. In the context of leachate treatment, the constraints of the process application include difficulties with the start-up procedure and the need for a higher process temperature. Furthermore, additional experience about the process is required, as its extensive research has been carried out mainly during the last decade. The detailed description of theoretical basis of novel biological nitrogen elimination technologies could be found in reviews [7,9].

No information about full-scale commercial anammox reactors commissioned at leachate treatment plants has been found in the literature. However, several full-scale installations, originally designed as nitrification reactors, have been operated for a long time with anaerobic ammonium oxidation of leachate due to the occasional shift of the process conditions towards those favourable for anammox bacteria. These are the rotating disk contactors at Pitsea (Great Britain), Mechernich (Germany) and Köllikon (Switzerland), where oxygen depletion due to the high nitrogen load together with low BOD content and sufficiently high process temperature $\left(25^{\circ} \mathrm{C}\right.$ or more) favoured local anoxic conditions [10]. Simultaneous partial nitrification, anammox and denitrification at low dissolved oxygen concentration $(\approx 0.3 \mathrm{~g} / \mathrm{l})$ and sufficiently long solid retention time (12-18 d) were observed in the aeration tanks of a leachate treatment plant in Taiwan [11]. The same combination of processes was also proved for a laboratory/scale rotating biological contactor [12].

The aim of the study, presented in this article, was to evaluate efficiency of nitrogen removal from leachate, derived from Filborna landfill (Helsingborg, Sweden) by conventional biological process (combined nitrification and denitrification in SBR), by novel biological treatment (one-reactor nitritation-anammox) and by chemical precipitation and to compare these three processes.

\section{LEACHATE COMPOSITION AND SAMPLING}

The leachate, which has been treated in the experiment, was delivered from Filborna landfill (NSR AB, Helsingborg). Its composition is typical for landfills in Sweden, where disposal of organic waste is prohibited. The landfill has a pond treatment system for leachate pretreatment before sending it to the municipal WWTP (see Figure 1). Flow equalization in a buffer pond is recommended in a leachate treatment system because of significant variations 


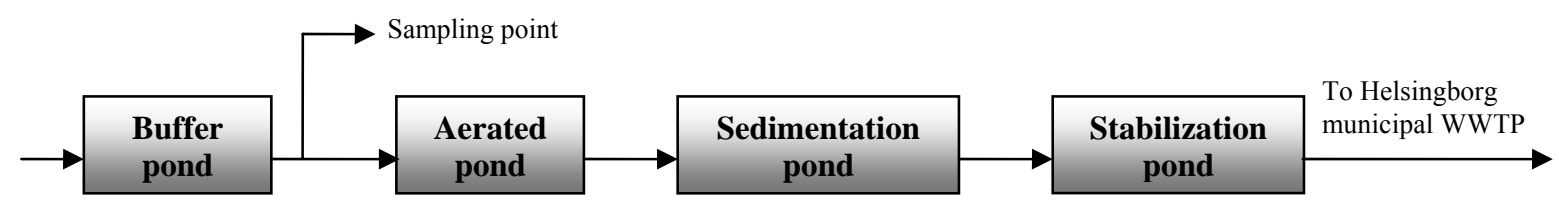

Figure 1. Current leachate treatment system at Filborna landfill.

Table 1. Composition of leachate from Filborna landfill.

\begin{tabular}{ll}
\hline \multicolumn{1}{c}{ Parameter } & Value \\
\hline Total nitrogen (unfiltered), mg/l & $156 \pm 21$ \\
Total nitrogen (filtered), mg/l & $137 \pm 17.3$ \\
$\mathrm{NH}_{4}-\mathrm{N}, \mathrm{mg} / \mathrm{l}$ & $120 \pm 15.4$ \\
$\mathrm{NO}_{3}-\mathrm{N}, \mathrm{mg} / \mathrm{l}$ & $1.7 \pm 1.4$ \\
$\mathrm{NO}_{2}-\mathrm{N}, \mathrm{mg} / \mathrm{l}$ & $0.27 \pm 0.09$ \\
Total phosphorous (unfiltered), $\mathrm{mg} / \mathrm{l}$ & $4.7 \pm 0.8$ \\
Total phosphorous (filtered), mg/l & $3.3 \pm 0.5$ \\
\hline
\end{tabular}

\begin{tabular}{ll}
\hline \multicolumn{1}{c}{ Parameter } & Value \\
\hline $\mathrm{PO}_{4}-\mathrm{P}, \mathrm{mg} / \mathrm{l}$ & $1.8 \pm 0.5$ \\
$\mathrm{COD}$ (unfiltered), mg/l & $482 \pm 45$ \\
$\mathrm{COD}$ (filtered), $\mathrm{mg} / \mathrm{l}$ & $452 \pm 56$ \\
$\mathrm{SS}, \mathrm{mg} / \mathrm{l}$ & $91 \pm 7.3$ \\
$\mathrm{VSS}, \mathrm{mg} / \mathrm{l}$ & $87 \pm 7$ \\
$\mathrm{pH}$ & $8.0 \pm 0.1$ \\
Alkalinity, ${\mathrm{mmol} \mathrm{HCO}_{3}}^{-} / 1$ & $24.8 \pm 2.7$ \\
\hline
\end{tabular}

in leachate volumetric flow and composition. Hence the samples for this study were taken between the buffer pond and the aerated pond. The composition of leachate from Filborna landfill, based on the measurements in 11 different samples, taken over a one-year period, is presented in Table 1.

\section{MATERIALS AND METHODS}

The experiments described below were carried out in laboratory scale. The analyses of total nitrogen, ammonium, nitrate and nitrite nitrogen, COD, total phosphorous and phosphorous of orthophosphates were performed using Dr. LANGE cuvette tests (LCK 114, LCK 138, LCK 303, LCK-339, LCK-342, LCK-348). Suspended solids (SS) and volatile suspended solids (VSS) were measured according to the standard SS-EN 872-1, pH - with WTW pH 320 pHmeter, dissolved oxygen - with oxygen analyzers WTW Oxi 197S and WTW inoLab Oxi 730.

\subsection{Combined nitrification and denitrification in a sequencing batch reactor}

A glass reactor with a total volume 51 was filled with 21 of activated sludge, taken from the denitrification basin of Källby municipal WWTP, Lund, Sweden. The leachate was pumped at the beginning of each 8-hour cycle to the reactor. 1-2 1 of leachate was treated per cycle, so that the total volume didn't exceed 41 . Nitrification was facilitated by aeration in the extended aerobic phase which lasted $5 \mathrm{~h}$. Denitrification (anoxic) phase with duration of $1.33 \mathrm{~h}$ followed the aerobic phase. Ethanol was used as a carbon source for the denitrification and pumped into the reactor at the beginning of the anoxic phase. The second aeration phase with a duration of $0.33 \mathrm{~h}$ was introduced for oxidation of organic matter which could be left after denitrification. The sedimentation phase lasted $1 \mathrm{~h}$ and the decanting phase $0.33 \mathrm{~h}$.

The reactor was operated at $20^{\circ} \mathrm{C}$ during 160 days. Ammonium, nitrate and nitrite nitrogen concentrations were regularly measured in the effluent. Nitrification and denitrification rates were measured by analyzing ammonium nitrogen (for nitrification) and nitrate nitrogen (for denitrification) in samples derived from the reactor at certain time intervals. 


\subsection{One reactor nitritation-anammox process}

A glass reactor with a total volume 31 was filled with 21 of leachate. The reactor contained plastic MBBR AnoxKaldnes K1 biocarriers (filling ratio $=16 \%$ ) with bacterial culture of ammonium oxidizing (nitritation) bacteria (upper layer of the biofilm) and anammox bacteria (bottom layer of the biofilm) (see Figure 2). The carriers were obtained from the full-scale one-reactor nitritation-anammox reject-water treatment process at Himmersfjärden WWTP, Stockholm, Sweden. The reactor was operated at $25^{\circ} \mathrm{C}$ during 65 days as a sequencing batch process with varied duration of the treatment cycles depending on the ammonium load and conversion rate. Mixing and aeration was continuous during the treatment cycles; the oxygen concentration in the reactor didn't exceed $2 \mathrm{mg} / \mathrm{l}$. The whole volume of leachate was exchanged after each treatment cycle to prevent nitrite accumulation. Ammonium, nitrate and nitrite nitrogen concentrations were regularly measured in the effluent. Ammonium conversion rate was measured by analyzing ammonium nitrogen in the samples derived from the reactor at certain time intervals.

\subsection{Struvite precipitation}

A glass reactor with a total volume of 11 was filled with 0.51 of leachate, which was continuously stirred with a magnetic stirrer. $\mathrm{MgCl}_{2} \cdot 6 \mathrm{H}_{2} \mathrm{O}$ and $\mathrm{NaH}_{2} \mathrm{PO}_{4} \cdot \mathrm{H}_{2} \mathrm{O}$ were added. This causes a $\mathrm{pH}$ drop, thus, $\mathrm{pH}$ adjustment with $1 \mathrm{M} \mathrm{NaOH}$ was started directly after the addition of chemicals to maintain the $\mathrm{pH}$ at the selected level (7.5 to 9.5, depending on the chosen conditions). The mixture was stirred during 2 minutes at $400 \mathrm{rpm}$ (fast mixing) and then during 10 minutes at $100 \mathrm{rpm}$ (slow mixing). The formed struvite was then allowed to settle during 10 minutes whereafter samples for $\mathrm{NH}_{4}-\mathrm{N}$ and $\mathrm{PO}_{4}-\mathrm{P}$ measurements were taken from the upper part of the reactor. The pump for $\mathrm{NaOH}$ addition was run at a constant speed of $0.1 \mathrm{ml} / \mathrm{s}$. Stopwatches were used to measure the operating time of the pump for calculation of lime consumption.

Bittern with $22.2 \mathrm{~g} \mathrm{Mg}^{2+} / 1$ was produced for replacement of magnesium salt of high purity by sea water evaporation. The sea water was taken from the Öresund at Barsebäckshamn, Skåne, Sweden. The initial concentration of $\mathrm{Mg}^{2+}$ in sea water was $400 \mathrm{mg} / \mathrm{l}$. The volume of water was decreased 110 times (from 101 to 0.09 l) to obtain the concentrated bittern.
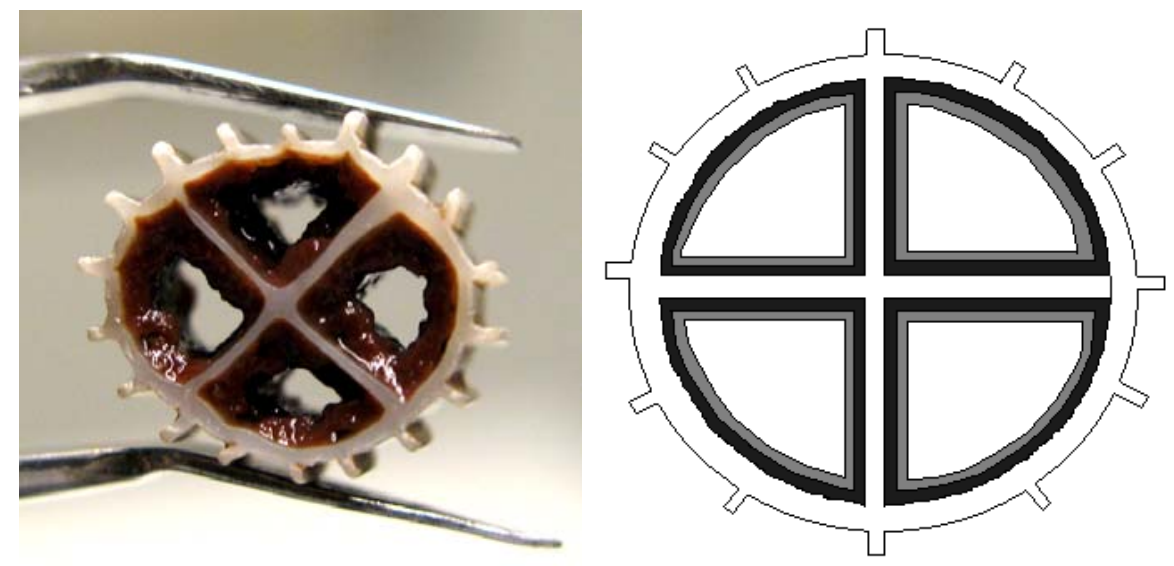

Figure 2. Plastic carrier with nitritation-anammox bacterial culture. Photo (to the left) and schematic drawing (to the right). Black colour on the drawing represents inner layer of anammox bacteria, grey colour - outer layer of nitrifying bacteria. 


\section{RESULTS}

Inorganic nitrogen concentrations in the effluent of the SBR were less than $1 \mathrm{mg} / \mathrm{l}$ as the experiment progressed, with only a few exceptions occurring because of technical problems (see Figure 3). Total nitrogen concentrations in the effluent were 10-12 mg/l. Removal of nitrogen in the combined nitrification/denitrification SBR process was efficient, since total nitrogen concentrations and ammonium nitrogen concentrations decreased $93 \%$ and $99 \%$, respectively. The nitrification rate was $23 \mathrm{mg} \mathrm{NH}-\mathrm{N} /(1 \cdot \mathrm{h})\left(3.6 \mathrm{mg} \mathrm{NH}_{4}-\mathrm{N} /(\mathrm{g} \mathrm{VSS} \cdot \mathrm{h})\right.$ ), denitrification rate was $180 \mathrm{mg} \mathrm{NO}-\mathrm{N} /(1 \cdot h)(28.7 \mathrm{mg} \mathrm{NO}-\mathrm{N} /(\mathrm{g}$ VSS $\cdot h))$. Only $30-40 \%$ of COD and $15-25 \%$ of phosphorous were removed, with final concentrations corresponding to 312-499 $\mathrm{mg} \mathrm{COD/1}$ and 0.7-2.3 $\mathrm{mg} \mathrm{PO}_{4}-\mathrm{P} / 1$, respectively.
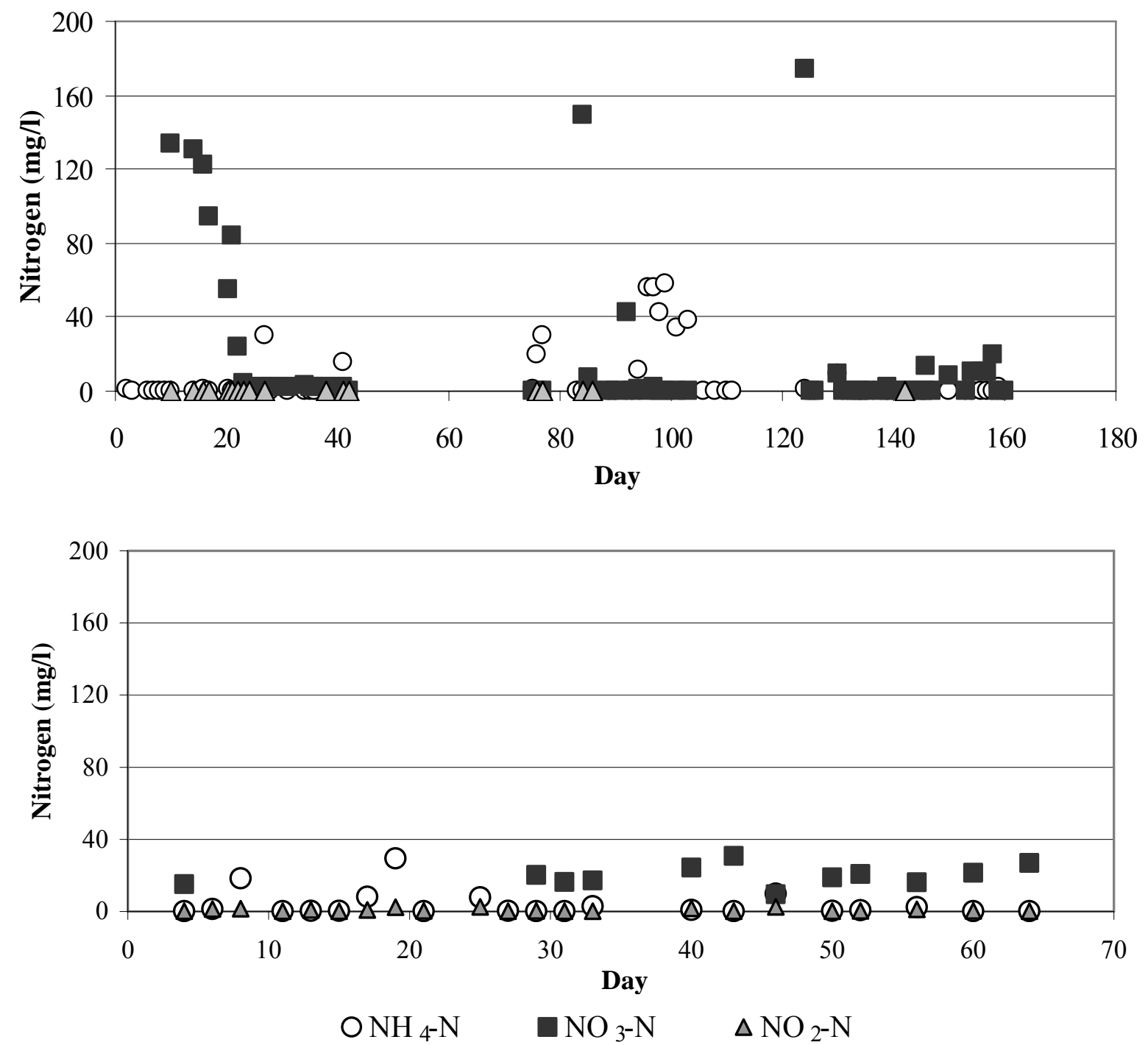

Figure 3. Inorganic nitrogen concentrations in the effluent of the combined nitrification/denitrification process (upper graph) and one-reactor nitritation-anammox process (lower graph).

One-reaction nitritation-anammox process in the MBBR showed a similar efficiency in ammonium nitrogen removal; $99 \% \mathrm{NH}_{4}-\mathrm{N}$ removal was achieved with $0.1 \mathrm{mg} \mathrm{NH} \mathrm{NH}_{4} \mathrm{~N} / 1$ in the 
effluent (see Figure 3). The effluent $\mathrm{NO}_{3}-\mathrm{N}$ concentrations varied between 15 and $25 \mathrm{mg} / \mathrm{l}$, as ca. $20 \%$ of nitrite, produced by nitrifiers in the first step of the process is converted to nitrate by anammox bacteria [7]. The determined ammonium conversion rate was between 2.7-3.7 $\mathrm{g}$ $\mathrm{NH}_{4}-\mathrm{N} /\left(\mathrm{m}^{2} \cdot \mathrm{d}\right)$. Conversion rates were calculated taken into account only inner surfaces of carriers, where bacteria grew. Organic removal was similar to that, achieved with combined nitrification/denitrification process (20-40\% of COD removed).

Struvite precipitation was carried out at different $\mathrm{Mg}: \mathrm{N}: \mathrm{P}$ ratios and different $\mathrm{pH}$. The increase of magnesium and phosphorous molar concentrations above the equilibrium level $(1: 1: 1)$ at $\mathrm{pH} 9.0$ improves nitrogen removal efficiency up to $95 \%$ with the lowest ammonium nitrogen concentration in the effluent equal to $6 \mathrm{mg} / \mathrm{l}$ at the $\mathrm{Mg}: \mathrm{N}: \mathrm{P}$ molar ratio 1.5:1:1.5 (see Figure 4).
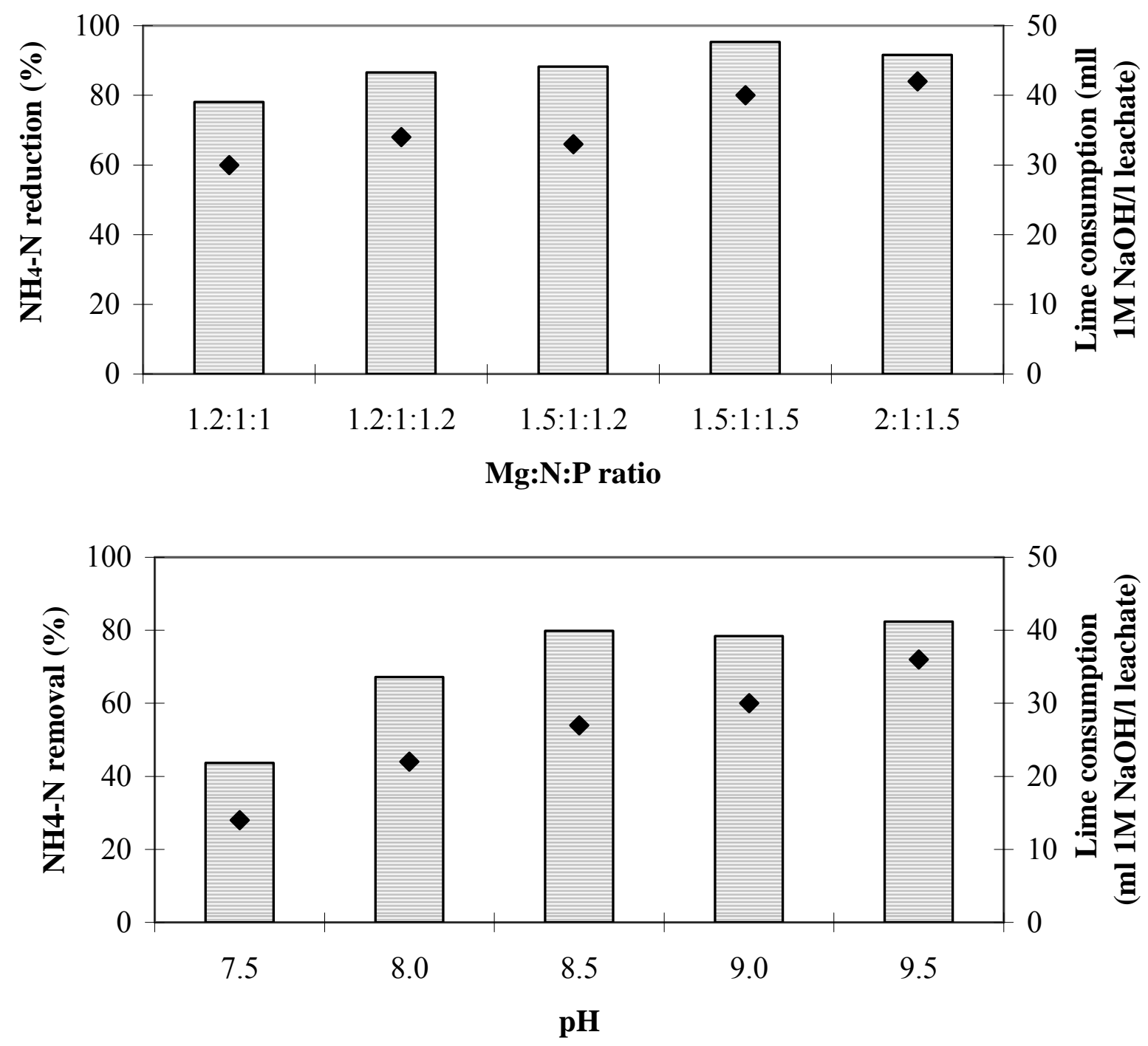

Figure 4. MAP precipitation: Reduction of $\mathrm{NH}_{4}-\mathrm{N}$ and lime consumption depending on different $M g: N: P$ ratios at $p H 9.0$ (upper diagram) and different $p H$ at $M g: N: P$ ratio 1.2:1:1 (lower diagram). Bars on the diagrams indicate ammonium removal (left scale), while dots indicate lime consumption (right scale).

High consumption of chemicals as well as high phosphorous concentrations in the effluent make the utilization of high $\mathrm{Mg}$ and $\mathrm{P}$ molar concentrations economically inefficient. Nitrogen removal significantly improves with increasing $\mathrm{pH}$ from 7.5 to 8.5 . In the $\mathrm{pH}$ range 
$8.5-9.5$ the changes in nitrogen removal efficiency are insignificant, but lime consumption for $\mathrm{pH}$ adjustment increases with $25 \%$ (see Figure 4). The most feasible conditions for struvite precipitation were found at $\mathrm{Mg}: \mathrm{N}: \mathrm{P}$ ratio 1.2:1:1, $\mathrm{pH}$ 8.5. An attempt to replace $\mathrm{MgNH}_{4} \mathrm{PO}_{4} \cdot 6 \mathrm{H}_{2} \mathrm{O}$ by bittern (concentrated sea water with high content of $\mathrm{Mg}$ salts) was successfully performed. When bittern was used as magnesium source, ammonium was removed down to the same concentrations, as with magnesium salts of laboratory purity. Addition of phosphorous for nitrogen precipitation resulted in a significant increase of phosphorous concentrations in the effluent with a concentration $20.8 \mathrm{mg} \mathrm{PO}_{4}-\mathrm{P} / 1$ after MAP precipitation at the applied $\mathrm{Mg}: \mathrm{N}: \mathrm{P}$ ratio 1.2:1:1 and $\mathrm{pH} 9.0$. Organic removal was fairly low (20-25\%), but comparable with removal achieved by the two tested biological processes.

Comparing the efficiency of the three processes it can be seen that it was possible to achieve $99 \%$ removal of ammonium nitrogen (less than $1 \mathrm{mg} \mathrm{NH}-\mathrm{N} / 1$ in the effluent) with both combined nitrification/denitrification process and one-reactor nitritation-anammox process, (see Figure 5). Struvite precipitation at $\mathrm{Mg}: \mathrm{N}: \mathrm{P}$ molar ratio 1.2:1:1 and $\mathrm{pH} 9.0$ resulted in lower ammonium removal ( $78 \%$ with $25 \mathrm{mg} \mathrm{NH}_{4}-\mathrm{N} / 1$ in the effluent).

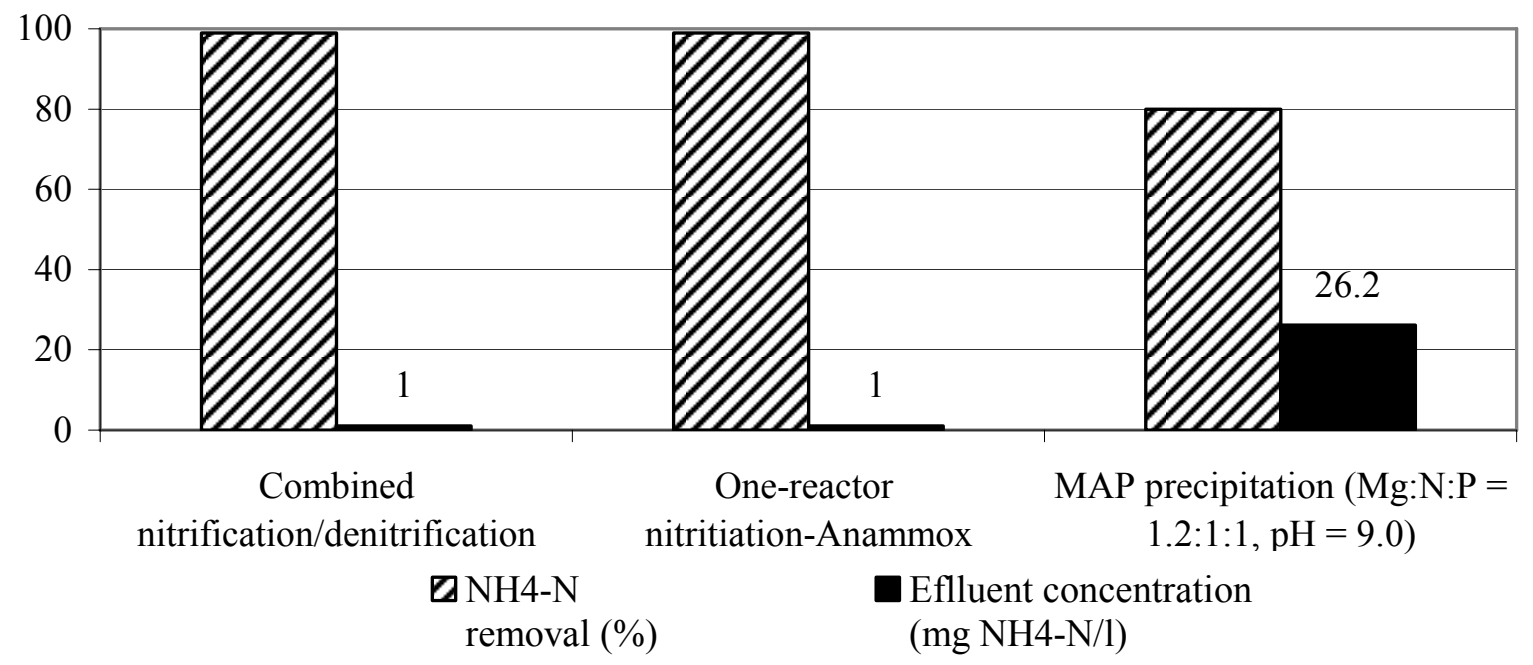

Figure 5. Ammonium nitrogen removal and effluent ammonium nitrogen concentrations: comparison between the three processes.

\section{DISCUSSION}

The choice of the right process for a full-scale wastewater treatment facility is always a decision which involves a compromise between the process costs and treatment efficiency. Leachate treatment technologies add additional complexities to the system design due to the higher concentrations of pollutants, their lower degradability and higher toxicity compared to municipal wastewater. For evaluation of toxicity effects, lab-scale trials should always precede the design step when biological treatment is considered. The three nitrogen removal processes compared in this study, are considered to be possible treatment strategies for the complete nitrogen removal from leachate at Filborna landfill. The results can also be taken into account by other landfill operators, who aim at upgrading of leachate treatment systems. Struvite precipitation allows about $80 \%$ ammonium nitrogen removal (or $25 \mathrm{mg} \mathrm{NH}-\mathrm{N} / 1$ in effluent). So, additional nitrogen removal will be required in case of direct release of the treated leachate to the environment, because the EU guidelines allow discharge of wastewater 
with nitrogen concentrations up to $15 \mathrm{mg} / \mathrm{l}$. Inability to reach the guideline values is not the only drawback of struvite precipitation. With a Mg:N:P molar ratio of 1.2:1:1, which was found to be the optimal one, magnesium salt with a concentration of $215 \mathrm{mg} \mathrm{Mg}^{2+} / 1$ and phosphorous salt with a concentration of $330 \mathrm{mg} \mathrm{P} / 1$ have to be added to the leachate. The latter also led to an increase of the phosphorous concentration in the effluent up to $400-500 \%$ of the initial concentration of phosphorous in the leachate. Magnesium salt can be replaced by bittern in regions proximate to sea, but the problem of sea water evaporation has to be solved in this case. Struvite precipitation requires $\mathrm{pH}$ adjustment throughout the process and ca. 30 $\mathrm{mg} / \mathrm{l}$ of $1 \mathrm{M} \mathrm{NaOH}$ was required to maintain the $\mathrm{pH}$ on the desired level. The use of concentrated chemicals also implies safety issues that have to be addressed. Struvite itself might cause clogging of pipes and equipment failures. The positive feature of struvite is the possibility of its utilization as a valuable fertilizer, thus, selling it to the farmers may partly reimburse costs for chemicals. Another positive feature of the process is its small footprint, as the installation can be quickly mounted on site and occupies only a few square meters. Overall, struvite precipitation may be feasible only with high nitrogen concentrations in the treated leachate, when biological processes require big reactor volumes and high expenses for aeration.

According to the obtained results, biological treatment processes are definitely more promising options for nitrogen removal, than chemical precipitation, as they allow $99 \%$ ammonium nitrogen removal. Leachate from Filborna landfill didn't contain toxic substances that significantly suppressed the metabolism of the microbial groups involved in the applied processes. Obtained nitrification and denitrification rates for the sequencing batch reactor are in accordance with earlier studies on the potential for leachate treatment from another landfill in southern Sweden [13]. Obtained ammonium reduction rate for the nitritation-anammox process in a MBBR $\left(3.7 \mathrm{mg} \mathrm{NH}-\mathrm{N} /\left(\mathrm{m}^{2} \cdot \mathrm{d}\right)\right)$ is significantly higher than the ammonium reduction rate at the Himmersfjärden WWTP $\left(1.9 \mathrm{mg} \mathrm{NH}_{4}-\mathrm{N} /\left(\mathrm{m}^{2} \cdot \mathrm{d}\right)\right)$, where the carriers were obtained from. It can be explained by lower filling ratio of the MBBR in the lab-scale studies, which can result in mass-transfer differences caused by down-scaling of the process.

Combined nitrification and denitrification is a conventional process widely used for nitrogen removal at municipal WWTPs. Designed in a sequencing batch configuration, it is a promising method for nitrogen reduction from leachate. Up to the year 2008, the process had been already installed at four leachate treatment plants in Sweden [3]. However, the process suffers from two main drawbacks: high aeration requirements and need for addition of external carbon source for denitrification. Both of them are resolved while applying onereactor nitritation-anammox process. On the other hand, not many researches on leachate treatment by the anammox process are done until today and no full-scale reactors have been commissioned yet, so, additional knowledge on the process is required. Moreover, one-reactor nitritation-anammox process doesn't solve the task of complete nitrogen removal, because the effluent contains $15-25 \mathrm{mg} \mathrm{NO}$ - $\mathrm{N} / 1$. Low removal of organic compounds by both biological methods is expected as leachate contains slowly biodegradable humic substances [5].

\section{CONCLUSIONS}

The lab-scale evaluation of chemical precipitation and two biological methods for nitrogen removal from leachate revealed a clear advantage for biological methods over chemical precipitation. The latter may be advantageous at higher nitrogen concentrations in leachate, especially if a small footprint of the plant is required. Among the studied biological methods for nitrogen reduction, one-reactor nitritation-anammox process can bring sizeable operational cost reduction, but is less examined and requires additional handling of nitrate nitrogen, which is formed in comparatively low concentrations as a byproduct. 


\section{ACKNOWLEDGEMENTS}

The research project was sponsored by the Crafoord Foundation. Experiments on leachate treatment in sequencing batch reactor were done in a scope of Master thesis work of Andrii Butkovskyi, supervised by professor Jes la Cour Jansen. Andrii's scholarship for Master studies was granted by the Swedish Institute. NSR AB and, especially, Magnus Svensson, contributed to the leachate delivery. Sara Stridh, being a process engineer at the Himmersfjärden WWTP, organised delivery of the carriers

\section{REFERENCES}

[1] Lee C.C., 2005. Environmental engineering dictionary, $4^{\text {th }}$ ed. Government Institutes, USA.

[2] A strategy for sustainable waste management: Sweden's waste plan. Swedish Environmental Protection Agency, 2005.

[3] Lakvatten från deponier (Leachate from landfills). Report \# 8306. Swedish Environmental Protection Agency, 2008 (in Swedish).

[4] Bengtsson M., Tillman A-M., 2004. Actors and interpretations in an environmental controversy: the Swedish debate on sewage sludge use in agriculture. Resources, Conservation and Recycling 42(1), 65-82.

[5] Renou S., Givaudan J.G., Poulain S., Dirassouyan F., Moulin P., 2008. Landfill leachate treatment: Review and opportunity. Journal of Hazardous Materials 150(3), 468-493.

[6] Abbas A.A., Jingsong G., Ping L.Z., Ya P.Y., Al-Rekabi W.S., 2009. Review on Landfill Leachate Treatments. Am. J. Appl. Sci., 6(4), 672-684.

[7] Schmidt I., Sliekers O., Schmid M., Bock E., Fuerst J., Kuenen J.G., Jetten M.S.M., Strous M., 2003. New concepts of microbial treatment processes for the nitrogen removal in wastewater. FEMS Microbiology Reviews, 27, 481-492.

[8] Stridh S., 2009. DeAmmon ${ }^{\circledR}$ vid Himmerfjärdsverket. Presentation at the Meeting "Anammox as a method for reject water treatment", Himmerfjärdsverket (in Swedish).

[9] Ahn Y-H., 2006. Sustainable nitrogen elimination biotechnologies: A review. Process Biochemistry, 41(8), 1709-1721.

[10] van der Star W.R.L., Abma W.R., Blommers D., Mulder J-W., Tokutomi T., Strous M., Picioreanu C., van Loosdrecht M.C.M., 2007. Startup of reactors for anoxic ammonium oxidation: Experiences from the first full-scale anammox reactor in Rotterdam. Water Research, 41(17) 4149-4163.

[11] Wang C-C., Lee P-H., Kumar M., Huang Y-T., Sung S., Lin J-G., 2010. Simultaneous partial nitrification, anaerobic ammonium oxidation and denitrification (SNAD) in a full-scale landfill-leachate treatment plant. Journal of Hazardous Materials, 175, 622-628.

[12] Cema G., Wiszniowski J., Zabczynski S., Zablocka-Godlewska E., Raszka A., SurmaczGorska J., 2007. Biological nitrogen removal from landfill leachate by deammonification assisted by heterotrophic denitrification in a rotating biological contactor (RBC). Water Science and Technology, 55(8-9), 35-42.

[13] Jönsson K., Andersson A., Heander E., La Cour Jansen J., 2009. Laboratory and pilot scale experiments for design of a leachate treatment facility at SYSAV Spillepeng. In: Proceedings from SARDINIA 2009, XII International Waste Management and Landfill Symposium, Sardinia, Italy. 